\title{
Wyrok Sądu Metropolitalnego w Katowicach (c. Sobański) z 9.12.1997 r. z tytułu niezdolności do podjęcia istotnych obowiązków małżeńskich
}

Ius Matrimoniale 4 (10), 265-271

1999

Artykuł został zdigitalizowany i opracowany do udostępnienia w internecie przez Muzeum Historii Polski w ramach prac podejmowanych na rzecz zapewnienia otwartego, powszechnego i trwałego dostępu do polskiego dorobku naukowego i kulturalnego. Artykuł jest umieszczony w kolekcji cyfrowej bazhum.muzhp.pl, gromadzącej zawartość polskich czasopism humanistycznych i społecznych.

Tekst jest udostępniony do wykorzystania w ramach dozwolonego użytku. 
Ius Matrimoniale 4 (1999)

\section{Wyrok Sadu Metropolitalnego w Katowicach (c. Sobański) z 9.12.1997 r. z tytuhu niezdolności do podjeccia istotnych obowiązków malżeńskich.}

\section{PRZEBIEG SPRAWY:}

ML oraz JW zawarli małżeństwo 4.10 .1975 w kościele parafialnym. Ważność tego małżeństwa zaskarżyła JW dnia 17.1.1983 w Sądzie Biskupim w (...) z czterech tytułów. Po rozmowie przeprowadzonej z notariuszem Sądu zredukowała tytuły nieważności do dwóch, mianowicie do wykluczenia dobra wiary oraz do przymusu i bojaźni. Konsekwentnie Sąd ustalił przedmiot sporu w formie pytania: czy udowodniono nieważność małżeństwa $z$ tytułu braku zgody spowodowanej przymusem i bojaźnią oraz wykluczeniem wierności po stronie kobiety? Na obydwa te pytania Sąd I instancji udzielił 6.3.1993 odpowiedzi negatywnej, czyli orzekł, iż nie udowodniono nieważności małżeństwa. Wskutek apelacji powódki sprawa znalazła się w II instancji. Na wniosek powódki Trybunał apelacyjny uzupełnił tytuł nieważności o niezdolność powódki do podjęcia istotnych obowiazków małżeńskich. Dnia 27.2.1997 Trybunał zatwierdzil wyrok I instancji orzekający, iż nie udowodniono nieważności małżeństwa ani z przymusu po stronie powódki ani $z$ tytuhu wykluczenia przez nią wierności, równocześnie jednak Trybunał stwierdził i orzekł, iż udowodniono nieważność małżeństwa z tytułu niezdolności powódki do podjęcia istotnych obowiązków małżeńskich. Za pośrednictwem oficjała Sądu w (...) powódka zwróciła się 24.4.1997 do Najwyższego Trybunału Sygnatury Apostolskiej o wyznaczenie któregoś z sądów kościelnych w Polsce do rozpatrzenia - zamiast w Trybunale Roty Rzymskiej - sprawy w trzeciej instancji. Dekretem z 13.5. 1997 wyznaczono Sąd Metropolitalny w Katowicach. Akta sprawy zostały wprawdzie tymczasem już wysłane do Trybunału Roty Rzymskiej, który jednak - uwzględniając dekret Sygnatury Apostolskiej - dosłał je 7.8. 1997 do Sądu Metropolitalnego w Katowicach. Dnia 23.9.1997 wyznaczono skład Sądu. Ponieważ strony nie przedstawiły dalszych wniosków do- 
wodowych, Sąd po zaznajomieniu się z uwagami obrońcy węzła małżeńskiego zamknał 27.10.1997 sprawę, a na sesji 9.12.1997 przystapił do orzekania w sprawie czyli do udzielenia odpowiedzi na pytanie, czy należy zatwierdzić wyrok II instancji w części orzekającej nieważność małżeństwa, co jest równoznaczne z pytaniem, czy udowodniono nieważność małżeństwa $z$ tytułu niezdolności powódki do podjęcia istotnych obowiązków małżeńskich.

\section{PRAWNY I FAKTYCZNY STAN SPRAWY。}

1. W sprawach prowadzonych z tytułów, o których w k.1095 n. 1-3, dużą wagę ma dowód $z$ opinii biegłych. Trybunał II instancji zasiegnął najpierw opinii pani psycholog i psychiatry, a następnie - na wniosek obrońcy węzła małżeńskiego zarzucającego,,brak odpowiedzi na istotne pytanie - zwrócił się o opinię do pani psycholog. Obydwie opinie są opracowane b. solidnie (pierwsza prawie 24 stron gestego maszynopisu, druga 16 stron!).

Pierwsza opinia, oparta na aktach sprawy oraz na psychiatrycznym badaniu powódki, kończy się stwierdzeniem, iż nie stwierdza się u powódki zaburzeń psychicznych, a jej przekonanie o nieważności małżeństwa nosi cechy „myślenia życzeniowego" - biegła nie znalazła ,chorobowych podstaw ani istotnych psychicznych uwarunkowań do podważenia ważności małżeństwa".

Druga biegła oparła swą opinię również na aktach sprawy oraz na badaniu psychologicznym. Wynik badań psychologicznych biegła ujmuje następująco: „, Wyniki badań psychologicznych mówia, ze jest to osobowość histeroidalna, którq charakteryzujq nastepujace cechy: reakcje dysocjacyjne, których celowość polega na znalezieniu usprawiedliwienia we wlasnych oczach z równoczesna tendencja do agrawacji czyli wyolbrzymiania istniejacych juz zaburzeń, czy trudności. Wlaściwości histeroidii wykazuja osobowości niedojrzate, które cechuje sktonność do zachowania teatralnego, podatność na uzaleznienia od otoczenia, przy równoczesnej tendencji do wywierania na nim presji $w$ dażeniu do osiagnięcia celów osobistych oraz sktonność do życzeniowego znieksztatcania rzeczywistości. Równocześnie wyniki badań informujacq o dość silnych mechanizmach obronnych, o sktonności do dyssymulacji, do przekonań urojeniowych, duzej dozie podejrzliwości $i$ wrazliwości na stosunki międzyludzkie, sktonności do kłopotów w życiu seksualnym". 
Całość danych prowadzi biegłą do wniosku o braku dojrzałości psychicznej powódki w chwili zawierania małżeństwa, przy czym ,za najważniejszy element tej niedojrzałości psychicznej należy uznać niedojrzałość emocjonalną, czyli brak dojrzałości w dziedzinie uczuć i popędów oraz niedojrzałość psycho-seksualną".

Biegła konkluduje: „Analiza całości danych wykazała, że w chwili zawierania małżeństwa osobowość powódki wykazywała cechy niedojrzałości emocjonalnej, psycho-seksualnej, a nawet intelektualnej w zakresie interpretowania realnych faktów przez pryzmat subiektywizmu. Osobowość powódki wykazywała również - potwierdzone później badaniami testowymi - cechy osobowości histeroidalnej. Ze względu na uwarunkowania psychiczne, osobowościowe, moralne, powódka nie byla zdolna do wypetnienia istotnych obowiqzków matzeniskich, dotyczy to przede wszystkim więzi uczuciowej, miłości, więzi fizycznej, wierności matżeńskiej, wspótbrzmienia partnerskiego. W chwilizawierania malzeństwa powódka była zdolna do nawiqzania prawdziwej więzi malżeńskiej, prawidtowych stosunków interpersonalnych z mę$\dot{z}$ em, budowania jedności małżeńskiej, wspólnoty życia $i$ mitości. Wprawdzie formalna jedność malzeńska - choć zaburzona wewnętrznie - trwata wiele lat, ale stanowiła podstawe stabilności zyciowej powódki, likwidowała jej lęk i obawę przed samotnościq. Małzeństwo z pozwanym byto dla niej bazq jej poczucia bezpieczeństwa, ale nie zaspokajato potrzeb uczuciowych, których poszukiwata lub oczekiwata na ich spetnienie poza matżeństwem, akceptujqc zdrade matżenskq. którq nazywata „,życiem w trójkacie”. Rozdwojenie jej sfery emocjonalnej jest wynikiem zaburzeń psychicznych, braku harmonii cech osobowości, dowodem dezintegracji osobowości".

2. Trybunał II instancji nie uzasadnil, dlaczego odrzuca opinię pierwszej biegłej a przychyla się do drugiej. Sąd nie jest władny wdawać się w dyskusję czy wręcz polemikę psychiatryczną czy psychologiczną, może jedynie ocenić spójność wywodów oraz ich oparcie w udowodnionych faktach.

Jest faktem, podkreślanym już w wyroku Trybunału I instancji, że decyzja ślubna powódki była podjęta w trudnych dla niej warunkach: samobójstwo ojca, śmierć matki, fiasko chęci zawarcia małżeństwa z RS. Jak zeznaje, gdy RS powiedział powódce, że jej nie kocha, próbowała go zastraszyć próbą samobójstwa - przeżywała wtedy lęki, miała silne nerwice (II,42). Pozwany zeznat o niej: „Powódka jest nerwowa, zmienna w nastrojach. Lubiła histeryzować. $Z$ drobnych spraw robila wielkie rze- 
czy. Z usposobienia zimna, sztywna stosuje się do pewnych przepisów. Jest niezwykle uparta. Lubi się samodręczyć. Potrzebuje sukcesówi czuje się niedowartościowana. Czuta lęk przed chorobq matki. Z tej przyczyny bata się ze mnq wspótzyć, by po urodzeniu drugiego dziecka nie zachorowata podobnie jak jej matka".

Wobec rozpatrywanego tytułu nieważności nie można nie zwrócić uwagi na zeznania pozwanego złożone w I i II instancji, wedle którego małżeństwo układało się dobrze, wręcz idealnie, przez siedem lat. Powódka w obydwu instancjach zeznała, że od początku pojawiły się nieporozumienia $\mathrm{z}$ powodu jej niechęci do współżycia płciowego z pozwanym. W piśmie z 19.2.1995 pozwany, po „długich rozmyślaniach” i patrząc już bez emocji, stwierdza, że małżeństwo było dlań ,jedną wielką udręką". Pisze: , Żona nie potrafita stworzyć ciepta domowego ogniska. Musiatem we wszystkim ulegać, gdyz stosowała wobec mnie szantaż psychiczny. Sam zajmowatem się domem, gotowaniem, sprzqtaniem, dzieckiem. Dla żony te sprawy nie miaty żadnego znaczenia. Dla niej najważniejsze byto zaspokoic swoje ambicje sportowe i zawodowe. Nawet kiedy byta $w$ zaawansowanej ciązy, plywata w maratonach narażajac życie dziecka". Ten ostatni fakt jest w aktach udokumentowany kopią dyplomu dla „uczestnika (...) maratonu pływackiego", jaki wystawiono powódce w r.1977. Powódka twierdzi, że mimo awersji seksualnej do męża, starała się przez blisko 10 lat dotrzymać słów przysięgi małżeńskiej, ,tak jak ją rozumiała w dniu ślubu". Pozwany nie był w stanie zaspokoić jej potrzeb seksualnych ze względu na jej związki uczuciowe z RS., a po uwolnieniu się od nich odczuwała potrzebę ,platonicznej miłości”, co jednak nie przeszkodziło jej erotyczno-seksualnemu pociagowi ku WW. Czytając zeznania i wyjaśnienia powódki dotyczącej sfery pożycia seksualnego trudno nie zgodzić się z biegła, że jest w nich „sporo nicjasności, nieścisłości, niekonsekwencji, sprzeczności".

Zeznania świadków niewiele wnoszą do sprawy: świadkowie nie zauważyli niczego szczególnego w pożyciu stron (z wyjątkiem dominacji powódki nad pozwanym): przez ,parę lat ich życie układało się dobrze" do takiego stwierdzenia można sprowadzić zeznania świadków. Na odnotowanie zasługuje wypowiedź koleżanki powódki ze studiów, JZ: „u niej emocje górowały nad zdrowym rozsądkiem..., jak sobie coś ubzdurała, to tak musiało być, ona za wszelką cenę dążyła do tego wytkniętego celu". Trudno nie zauważyć - co podkreśla też biegła - że ambicje przerastały faktyczne możliwości powódki (sukcesem było ukończenie długodystansowych zawodów). Ze względu na tytuł sprawy trzeba też zwró- 
cić uwagę na zeznanie RS: ,nie doszło do ślubu, bo nie pasujemy do siebie, ona była dla mnie zbyt infantylna i nie traktowałem jej jako partnerki, tylko jako dziecko" - świadek jest niespełna dwa lata starszy od powódki!

3. Konieczną do wyrokowania pewność moralną Sąd, ,winien czerpać z faktów i dowodów” (k.1608 §2). „Fakty” to wszelkie zaszłości procesowe, w tym także stanowiska zajmowane przez strony. Powódka zajmowała stanowisko wielokrotnie i to w pismach nader obszernych, thumacząc raz po raz, jak należy rozumieć jej wypowiedź. Skarga z 9.1.1987 wynosi 14 stron, pismo apelacyjne 11 , stron. W tym ostatnim zarzuca Trybunałowi I instancji ,sztywne trzymanie się gotowych, podręcznikowych schematów" (z podkreśleniem!), nietrafną interpretację zeznań, zaniedbania powodujące trudności w dotarciu do prawdy, nieodpowiednie formułowanie pytań oraz brak uwzględnienia i zrozumienia „diametralnie różnej sytuacji psychologicznej i społecznej". Akta sprawy I instancji nie dają podstaw do stawiania takich zarzutów. Lektura pism powódki każe uznać za zasadną opinię biegłej: „Bardzo charakterystyczną cechą powódki jest to, że stosuje ona w swoich obszernych wywodach opartych na spekulacjach myślowych taktykę obarczania otoczenia brakiem zgody z jej poglądami. Zarzuca swoim świadkom stosowanie mechanizmów obronnych w zeznaniach, które są odmienne od jej opinii, wynikającej z bardzo subiektywnej oceny sytuacji. Świadczy to również o jej braku zdolności do obiektywnego spojrzenia na realną rzeczywistość i nieliczenie się z tą rzeczywistością.

Bardzo ostro zareagowała na uwagę obrońcy węzła małżeńskiego, który stwierdził, że jej także można zaimputować mechanizmy obronne. Argumentem za nieprzemyślane - jej zdaniem - powyższe uwagi, jest jej dążenie do dojrzalej osobowości, o co się stara, a ta zakłada przecież umiejętność demaskowania mechanizmów obronnych...

I znowu spekulacje, teoretyzowanie, psychologizowanie. Nie tylko świadkom zarzuca powódka stosowanie mechanizmów obronnych, ale również przesłuchującym wytworzenie stresującej atmosfery podczas przesłuchiwania np. ciotki ES, co jest o tyle nietrafne, że świadek ten przesłuchiwany w drugiej instancji, także nie wniósł nic nowego do sprawy, potwierdził swoje poprzednie zeznania, sprzeczne $z$ opiniami powódki. Powyższe spekulacje myślowe powódki wskazują na skłonności do przerzucania na otoczenie odpowiedzialności za własne niepowodzenia, są dowodem jej subiektywnego, oderwanego od rzeczywistości widzenia problemu, z silną tendencją do stosowania mechanizmów obron- 
nych, które - jak wiadomo - chronią człowieka przed przyjęciem do wiadomości opinii niekorzystnej o sobie samej. Powódka stosuje również mechanizm racjonalizacji, czyli dobieranie pozornie rozsądnego wytłumaczenia dla własnego postępowania, mającego $w$ istocie inne przyczyny”. Zeznania i wywody powódki są „subiektywnie szczere”, ale - wedle biegłej - ,niewiele mają wspólnego z obiektywizmem". Niewatpliwie zeznania te noszą - co podkreśla pierwsza biegła - „cechy myślenia życzeniowego", co właśnie - jak zauważa druga biegła - jest jedną z cech niedojrzałości psychicznej.

W świetle całości akt sprawy zasadna wydaje się opinia biegłej, że u powódki „można stwierdzić dezintegrację osobowości polegającą na dysharmonii między różnymi ,sferami psychicznymi, niedojrzałość emocjonalną oraz cechy histeryczne.

4. Pierwsza skarga wniesiona przez powódkę do Sąu Biskupiego $\mathrm{w}(\ldots)$ wnosi o orzeczenie nieważności małżeństwa $z$ czterech tytułów, dopiero rozmowa w Sązie pozwoliła doprecyzować dwa tytuły, $z$ których prowadzono sprawę $w$ pierwszej instancji. Wnosząc apelacje powódka dostrzegła jeszcze jeden tytuł nieważności. Podniesienie tylu tytułów nieważności dowodzi - żywionego od r.1985 - przekonania powódki o nieważności małżeństwa przy równoczesnej trudności wskazania podstaw tej nieważności. Obrońca węzła małżeńskiego II instancji słusznie postawił pytanie, czy powódka pod wpływem ,nagłego i głębokiego nawrócenia" nie dokonuje reinterpretacji faktów i zdarzeń". Biegła daje w świetle pism powódki zasadne, zdaniem Sądu - thumaczenie przekonania powódki o nieważności małżeństwa. Wynikło ono $z$ napięć wewnętrznych, jakie u powódki rodziło małżenstwo, które usiłowała godzić $z$,życiem w trójkącie". Pobieżne zaznajomienie się z prawem kanonicznym doprowadziło ją do wniosku, że małżeństwo jest nieważne $\mathrm{z}$ powodu braku rozeznania i błędnego rozeznania, braku wolności i równoczesnego zamiaru kontynuowania związków z RS. Powódka nie dostrzega sprzeczności w tych tytułach, które przecież się wykluczają. Powódka pisze w wywodzie apelacyjnym, że ,gdy zawierała małżeństwo, pojawiła się u niej refleksja „co ja robię, przecież ślub to poważna sprawa, a ja w ogóle tego nie przemyślałam". Tym samym powódka przekreśla zasadność tamtych tytułów nieważności, a przyznaje, że jej decyzja na małżeństwo nie wynikła z obiektywnego, realnego patrzenia na sprawy $\mathrm{i}$ ich oceniania.

Zasadna jest przeto konkluzja biegłej, że „w przypadku powódki występują wszystkie wyżej (tj. w opinii biegłej) wymienione elementy i uwa- 
runkowania jej niedojrzałości psychicznej, emocjonalnej i psycho-seksualnej, które są czynnikami mającymi ujemny wpływ na powstanie więzi małżeńskiej i na pomyślność związku małżeńskiego".

Stusznie przeto Trybunał II instancji - zatwierdziwszy wyrok Trybunału I instancji - skoncentrował się na nowym tytule sprawy wprowadzonym na stopniu apelacyjnym. Stopień dojrzałości wymaganej do zawarcia małżeństwa wyznaczają dwie zasady, które trzeba uwzględnić łącznie. Pierwsza z nich to prawo każdego człowieka do zawarcia małżeństwa, druga to natura małżeństwa i wynikające stąd wymogi dotyczące zdolności prawnej do zawarcia małżeństwa. „Fakty i dowody” znajdujące się w aktach sprawy prowadzą Sąd do wniosku, że powódce zawierającej małżeństwo brakowało dojrzałości odpowiedniej do małżeństwa. Brakowało jej osobowej zdolności do oddania się drugiej osobie, zaakceptowania jej i „bycia dla niej”. Istotne dla małżeństwa „wyjście poza siebie" transcendencja na drugiego człowieka, przekraczała jej możliwości.

Małżeństwo powstaje przez akt „woli, którym mężczyzna i kobieta w nieodwołalnym przymierzu wzajemnie się sobie oddają i przyjmują w celu stworzenia małżeństwa" (k.1057 §2). Tego oddania się i przyjęcia partnera na wspólnotę całego życia nie było po stronie powódki, a nie było dlatego, że tak rozumiane małżeństwo przerastało jej możliwości.

Tak więc Sąd Metropolitalny orzeka, iż udowodniono nieważność małżeństwa $z$ tytułu niezdolności powódki do podjęcia istotnych obowiązków małżeńskich. Tym samym Sąd zatwierdza wyrok II instancji w części orzekającej nieważność małżeństwa. 